\title{
Characterization of Human Lymphocyte $N$-Acetyltransferase and Its Relationship to the Isoniazid Acetylator Polymorphism
}

\author{
Charlene A. McQueen ${ }^{1,2}$ and Wendell W. Weber ${ }^{1}$
}

Received 6 Sept. 1979-Final 28 Nov. 1979

Characterization of human lymphocyte N-acetyltransferase (NAT) for specific activity, substrate specificity, inhibition, $p H$ optimum, apparent $K_{m}$, kinetic mechanism, trypsin stability, freezing stability, and heat stability was carried out in rapid and slow isoniazid (INH) acetylators. There is a statistically significant difference in the heat stability of lymphocyte NAT from rapid and slow INH phenotypes. The lymphocyte enzyme from rapid INH acetylators is less heat stable than the lymphocyte enzyme from slow INH acetylators. This is an indication of a structural, possibly polymorphic, difference in lymphocyte $N A T$ from the two acetylator phenotypes.

KEY WORDS: $N$-acetyltransferase; isoniazid acetylator polymorphism; heat stability.

\section{INTRODUCTION}

Acetylation is an important metabolic route for inactivation of drugs and carcinogens that are arylamines or hydrazine derivatives. The reaction, catalyzed by $\mathrm{N}$-acetyltransferases (NAT), involves the transfer of the acetyl group from acetyl coenzyme A (AcCoA) to the arylamine substrate (Lipmann, 1945). Individuals are classified as rapid or slow acetylators according to the rate at which drugs such as isoniazid (INH) or sulfamethazine (SMZ)

This work was supported by U.S. Public Health Service Grant GM 27028 and GM 21723. A preliminary report of this work was presented to the American Society of Human Genetics, San Diego, California, October 1977.

${ }^{1}$ Departments of Human Genetics and Pharmacology, University of Michigan, Ann Arbor, Michigan 48109.

${ }^{2}$ Present address: Division of Pathology and Toxicology, Naylor Dana Institute for Disease Prevention, American Health Foundation, Valhalla, New York 10595. 
are acetylated by liver NAT (Knight et al., 1959; Evans et al., 1960). The slow acetylator phenotype is homozygous recessive while the rapid acetylator phenotype is heterozygous or homozygous dominant. Both man and the rabbit possess this INH acetylator polymorphism (Knight et al., 1959; Evans et al., 1960; Frymoyer and Jacox, 1963; Gordon et al., 1973).

An extrahepatic polymorphism has also been described in the rabbit that involves the acetylation of $\mathrm{p}$-aminobenzoic acid (PABA) and is related to the INH phenotype (Weber et al., 1975, 1976; Szabadi et al., 1978). Rapid INH acetylator animals have low blood PABA NAT while the slow phenotype has high blood PABA NAT. This relationship is also seen in lymphocytes as well as red blood cells (Weber et al., 1976).

Although previous studies have failed to detect any relationship between extrahepatic NAT and the INH phenotype in man, activity has been the only criterion used (Motulsky and Steinmann, 1962; Drayer et al., 1974; Hearse et al., 1970). Alterations in the enzyme could affect any of its biochemical properties (Paigen, 1971). This study was undertaken to determine whether there are differences in the genetic and biochemical characteristics of human lymphocyte NAT that are associated with different INH acetylator phenotypes.

\section{MATERIALS AND METHODS}

\section{Determination of Acetylator Phenotype}

Individuals were phenotyped as rapid or slow INH acetylators by a slight modification of the method of Evans (1969). Blood and urine samples were obtained from healthy adult volunteers who had not eaten for $2 \mathrm{hr}$ prior to the test. SMZ $(10 \mathrm{mg} / \mathrm{kg})$ was given orally, and blood and urine samples were collected $4 \frac{1}{2} \mathrm{hr}$ later. The percent of acetylated drug was then determined (Weber and Brenner, 1974).

\section{Separation of Peripheral Lymphocytes}

The method developed by Böyum (1967) and modified by Lopes et al. (1973) was used to separate lymphocytes from peripheral blood samples. The gradient mixture was prepared by combining 2.4 parts of $9 \%$ Ficoll 400 (9 $\mathrm{g} / 100 \mathrm{ml} 1 \times 10^{-2}$ Tris- $\left.\mathrm{HCl}, p \mathrm{H} 7.4\right)$ with 1 part Hypaque mixture $(45.3 \mathrm{ml}$

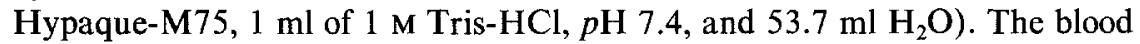

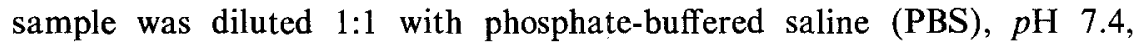
layered on the gradient mixture (ratio of sample to gradient mixture is 2:1) and centrifuged for $30 \mathrm{~min}$ in a GLC II (Sorvall, Norwalk, Connecticut) at $400 \mathrm{~g}$. After the mononuclear layer had been washed, the cells were counted, 
divided into aliquots, and centrifuged for $10 \mathrm{~min}$ at $1300 \mathrm{~g}$ in a GLC II. The supernatant was removed and the cell pellet stored at $-70 \mathrm{C}$ in an ultrafreezer.

\section{Assay for PABA NAT Activity}

Samples were assayed for enzyme activity using a spectrophotometric microassay system (Hearse and Weber, 1973). A cell pellet was resuspended in 0.1

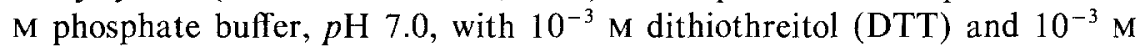
ethylenediamine tetraacetic acid (EDTA) to give a concentration of approximately $10 \times 10^{6}$ cells $/ \mathrm{ml}$. This suspension was subjected to eight to ten rounds of freezing in a dry ice and methanol bath and thawing in a 37C water bath in order to lyse the cells. Fifty microliters of the lysate was used to determine enzyme activity.

\section{Culture of Human Peripheral Lymphocytes}

Lymphocytes were maintained in culture according to the method of Bloom and Iida (1967). The cell culture medium was prepared by adding fetal calf serum $(10 \% \mathrm{v} / \mathrm{v})$, penicillin (50 units $/ \mathrm{ml})$, and streptomycin $(50 \mu \mathrm{g} / \mathrm{ml})$ to RPMI 1640, minus PABA (Flow Laboratories, Rockville, Maryland). Isolated lymphocytes were added to the medium to give a concentration of approximately $5 \times 10^{5}$ cells $/ \mathrm{ml}$. Ten milliliters of the cell and medium suspension was pipetted into a T25 flask with $0.1 \mathrm{ml}$ of phytohemagglutinin (Burroughs Wellcome, Research Triangle Park, North Carolina) and incubated at $37 \mathrm{C}$ in a $5 \% \mathrm{CO}_{2}$ atmosphere.

\section{Protein Determinations}

The amount of protein in a cell lysate was determined by a microbiuret reaction (Gornall et al., 1949).

\section{Experimental Conditions for Comparative Determinations of Lymphocytes NAT from Rapid and Slow INH Acetylators}

\section{Substrate Specificity}

All compounds were assayed for substrate potential for lymphocyte NAT by the procedure described for determination of PABA NAT activity. The final concentration of substrate was 4.4. $\times 10^{-5} \mathrm{M}$ in all cases.

\section{Inhibition}

Cell pellets were resuspended with $0.1 \mathrm{M}$ potassium phosphate buffer, $p \mathrm{H}$ 7.0, to a concentration of approximately $20 \times 10^{6} \mathrm{cells} / \mathrm{ml}$ and lysed by freezing 
and thawing as previously described. Twenty-five microliters of the cell lysate was used in the enzyme assay. The test compound $(25 \mu 1)$ at the appropriate concentration was added to the incubation mixture and the procedure followed as previously described.

\section{pH Optimum}

$p \mathrm{H}$ optimum curves were determined in $0.1 \mathrm{M}$ potassium pyrophosphate buffer adjusted to the desired $p \mathrm{H}$ with $\mathrm{HCl}$. Cell samples, isolated from a single individual, were each resuspended to a final concentration of $10 \times 10^{6}$ cells $/ \mathrm{ml}$ in buffer at several specific $p \mathrm{H}$ 's, and lysed by repeated freezing and thawing. Enzyme activity was determined as previously described.

\section{Stability to Freezing}

The cell lysate was divided into aliquots and stored at $-20 \mathrm{C}$. Enzyme activity was determined on a freshly thawed sample at specified time intervals.

\section{Trypsin Inactivation}

The cell pellet was resuspended in $0.1 \mathrm{M}$ phosphate buffer, $p \mathrm{H} 7.0$, with $10^{-3}$ $M$ DTT and $10^{-3}$ EDTA to a concentration of approximately $17 \times 10^{6}$ cells/ml. Thirty microliters of the cell lysate was added to a 400- $\mu 1$ tube, and a $10-\mu 1$ aliquot of $0.01 \%$ trypsin solution (Worthington Biochemical Corp., Freehold, New Jersey) was then added. The mixture was incubated in a $33 \mathrm{C}$ water bath for specified times, and the action of the trypsin was stopped by the addition of $10 \mu \mathrm{l}$ of $0.01 \%$ soybean trypsin inhibitor (Worthington Biochemical Corp., Freehold, New Jersey). The samples were then assayed for residual PABA NAT activity by the procedure previously described.

\section{Stability to Heat}

Fifty-microliter aliquots of the cell lysate $\left(10 \times 10^{6}\right.$ cells $\left./ \mathrm{ml}\right)$ were placed in 400- $\mu$ l tubes. The samples were then placed in an Aquatherm water bath (New Brunswick Scientific Co., New Brunswick, New Jersey) at 44C, heated for a specified time, removed, and placed on ice. Blanks and zero-time samples were kept on ice and then assayed with the experimental samples for PABA NAT activity by the assay previously described.

\section{RESULTS}

Healthy adult volunteers were phenotyped as rapid or slow acetylators of SMZ by determining the percent of acetylated drug in blood and urine 
(Evans, 1969; Weber and Brenner, 1974). Slow acetylators had less than 75\% acetylated drug in urine and $40 \%$ in blood, while rapid acetylators had greater than $80 \%$ in urine and $45 \%$ in blood.

Differential cell counts were done on the mononuclear layer obtained in the Ficoll Hypaque gradient, and almost equal numbers of lymphocytes and monocytes were present. After this fraction had been washed, almost $90 \%$ of the monocytes were removed, so the final preparation contained appproximately $6 \%$ monocytes. NAT activity was sought in a purified preparation of monocytes and none was detected. Therefore, the monocyte contribution to PABA NAT activity in the mononuclear cell fraction was negligible.

The biochemical characteristics of lymphocyte NAT from rapid and slow INH acetylators were determined. Comparisons of specific activity, substrate specificity, kinetic properties, inhibitors, $p \mathrm{H}$ optimum, and stability were made.

Table I. Specific Activity of Lymphocyte PABA NAT from Rapid and Slow INH Acetylators

\begin{tabular}{|c|c|c|c|}
\hline \multicolumn{2}{|c|}{ Rapid INH acetylators } & \multicolumn{2}{|c|}{ Slow INH acetylators } \\
\hline Donor & $\mathrm{nmol}$ AcPABA $/ \mathrm{hr} / \mathrm{mg}$ & Donor & nmol AcPABA $/ \mathrm{hr} / \mathrm{mg}$ \\
\hline ML & 105 & BW & 106 \\
\hline $\mathbf{A A}$ & 114 & EP & 108 \\
\hline PS & 116 & GG & 113 \\
\hline SL & 119 & $\mathrm{CAS}$ & 113 \\
\hline LB & 120 & RT & 121 \\
\hline IG & 131 & LH & 124 \\
\hline $\mathrm{VZ}$ & 134 & $\mathrm{CS}$ & 127 \\
\hline SB & 136 & $\mathrm{FC}$ & 130 \\
\hline WB & 141 & WV & 136 \\
\hline PN & 142 & $\mathrm{CM}$ & 144 \\
\hline DK & 146 & $\mathrm{KL}$ & 145 \\
\hline $\mathrm{HE}$ & 150 & JS & 148 \\
\hline MV & 169 & DG & 149 \\
\hline JB & 171 & SH & 152 \\
\hline \multirow[t]{10}{*}{ DR } & 178 & $\mathrm{CH}$ & 158 \\
\hline & & HR & 158 \\
\hline & & KM & 170 \\
\hline & & BB & 172 \\
\hline & & PDS & 172 \\
\hline & & OL & 173 \\
\hline & & $\mathrm{DH}$ & 174 \\
\hline & & MAL & 207 \\
\hline & & WW & 215 \\
\hline & & RV & 225 \\
\hline MEAN & 138 & & 151 \\
\hline SD & 22 & & 32 \\
\hline$N$ & 15 & & 24 \\
\hline
\end{tabular}




\section{Specific Activity}

The activity of lymphocyte NAT (nmol acetyl p-aminobenzoic acid (AcPABA) formed $/ \mathrm{hr} / \mathrm{mg}$ protein) was determined for both INH acetylator phenotypes. The range of NAT activity in the slow phenotype was 106-225 and was 105-178 in the rapid phenotype (Table I). No relationship was observed between the specific activity of NAT in the lymphocyte and the acetylator phenotype.

\section{Substrate Specificity}

The ability of lymphocyte NAT to acetylate SMZ, benzocaine, and procainamide as well as PABA was tested. PABA was the only acetyl acceptor found. NAT activity for SMZ, benzocaine, or procainamide was not detected in either acetylator phenotype.

\section{Kinetic Properties}

Initial velocities were determined for PABA and AcCoA using lymphocytes from six individuals of both acetylator phenotypes and graphed as double reciprocal (Lineweaver-Burk) plots. No differences were detected in the $K_{m}$ or $V_{\max }$ values obtained from each acetylator phenotype. Average $K_{m}$ values of $1.71 \times 10^{-4} \mathrm{M}$ and $1.82 \times 10^{-4} \mathrm{M}$ were obtained for PABA and AcCoA, respectively, while average $V_{\max }$ values of 574 and $199 \mathrm{nmol} \mathrm{AcPABA} / \mathrm{hr} / \mathrm{mg}$ protein were obtained for PABA and AcCoA, respectively. The kinetic constants for PABA were determined at an AcCoA concentration of $2.43 \times$ $10^{-3} \mathrm{M}$ while the kinetic constants for AcCoA were determined at a PABA concentration of $4.4 \times 10^{-5} \mathrm{M}$. A series of initial velocity curves was run varying both substrates and yielded a series of parallel lines.

\section{Innhibitors}

Various metal ions were tested for their effect on lymphocyte NAT activity. The metal concentrations ranged from $10^{-3} \mathrm{M}$ to $10^{-7} \mathrm{M} . \mathrm{Fe}^{3+}, \mathrm{Mn}^{2+}, \mathrm{Ca}^{2+}$, and $\mathrm{Fe}^{2+}$ had no effect on enzyme activity, but $50 \%$ inhibition was seen at $10^{-5} \mathrm{M} \mathrm{Cu}^{2+}, 1.4 \times 10^{-4} \mathrm{M} \mathrm{Zn}^{2+}$, and $5.5 \times 10^{-6} \mathrm{M} \mathrm{Hg}^{2+} . N$-Ethylmaleimide, a sulfhydryl group inhibitor, was a potent inhibitor of the enzyme with a concentration of $1 \times 10^{-6} \mathrm{M}$ resulting in a $50 \%$ loss of activity. The products of the enzyme reaction, coenzyme $\mathrm{A}$ and AcPABA, were poor inhibitors. The addition of $10^{-3} \mathrm{M}$ AcPABA resulted in a $60 \%$ loss of enzyme activity and of $10^{-3} \mathrm{M}$ CoA an $18 \%$ loss. No activation of the enzyme was seen. The effects of all the compounds tested were the same for both acetylator phenotypes. 


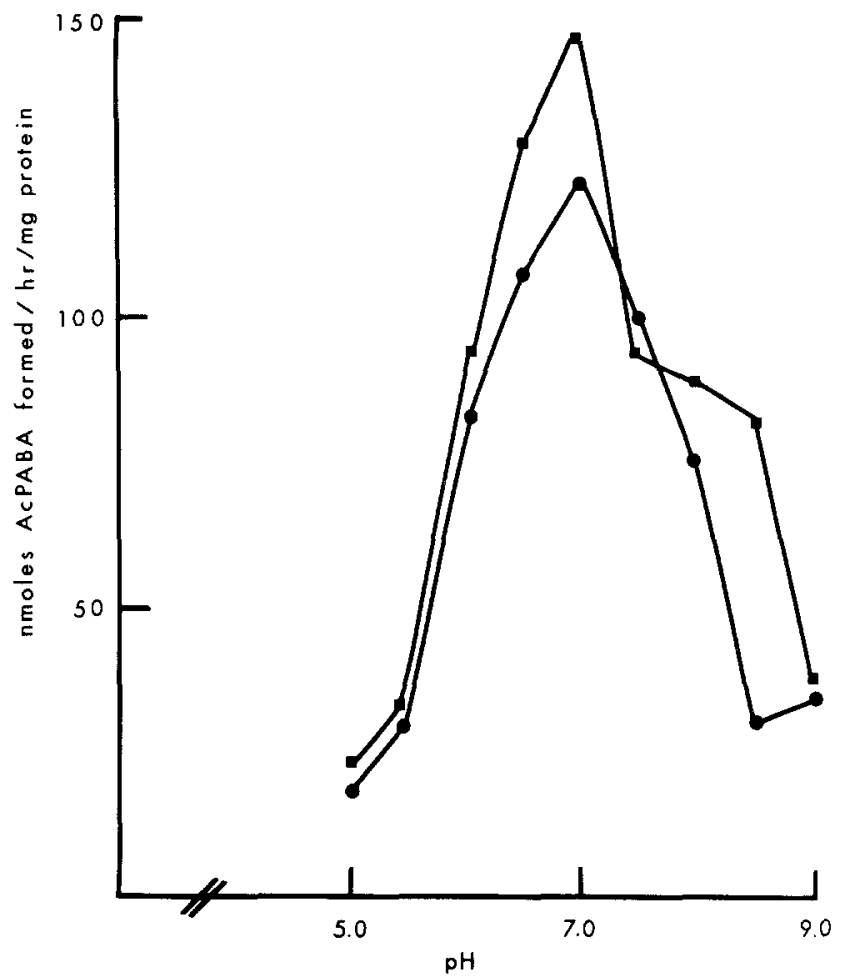


cells were lysed in $0.1 \mathrm{M}$ pyrophosphate buffer of varying $p \mathrm{H}$ 's and assayed for enzyme activity according to the procedure in Materials and Methods.

\section{pH optimum}

$p \mathrm{H}$ optimum curves were determined for human lymphocyte PABA NAT from rapid and slow INH acetylators. A $p H$ range of 5.0-9.0 $(0.5 p \mathrm{H}$ unit intervals) was used initially and both phenotypes had a peak of activity at $p \mathrm{H}$ 7.0 (Fig. 1). When a $p \mathrm{H}$ range of $6.2-7.8(0.2 p \mathrm{H}$ unit intervals) was used, the peak of activity was found to be broader, approximately 6.6-7.4. No significant differences were found between the $p \mathrm{H}$ curves from the two acetylator phenotypes.

\section{Stability}

The stability of lymphocyte PABA NAT to a variety of agents and conditions was tested. Lymphocyte lysates from both acetylator phenotypes were stored at $-20 \mathrm{C}$, then assayed for NAT activity. No differences were observed in the 
stability of activity during the first 18 days, and an average of $60 \%$ of the activity was still detectable between 21 and 72 days. Prior addition of AcCoA $\left.2.85 \times 10^{-3} \mathrm{M}\right)$ to the lysate did not exert a protective effect against storage at $-20 \mathrm{C}$.

Treatment of lymphocyte NAT from six individuals, three rapid and three slow acetylators, with $0.01 \%$ trypsin for varying time periods resulted in a $50 \%$ loss of activity in $13-22 \mathrm{~min}$. The average $t_{1 / 2}$ for the slow acetylators was $17 \mathrm{~min}$, the same average obtained for the rapid phenotype.

The effect of heating on lymphocyte NAT was initially determined at temperatures ranging from 30 to $53 \mathrm{C}$ for $5 \mathrm{~min}$. At temperatures less than $40 \mathrm{C}$, at least $90 \%$ of the enzyme activity was still present after 5 min of

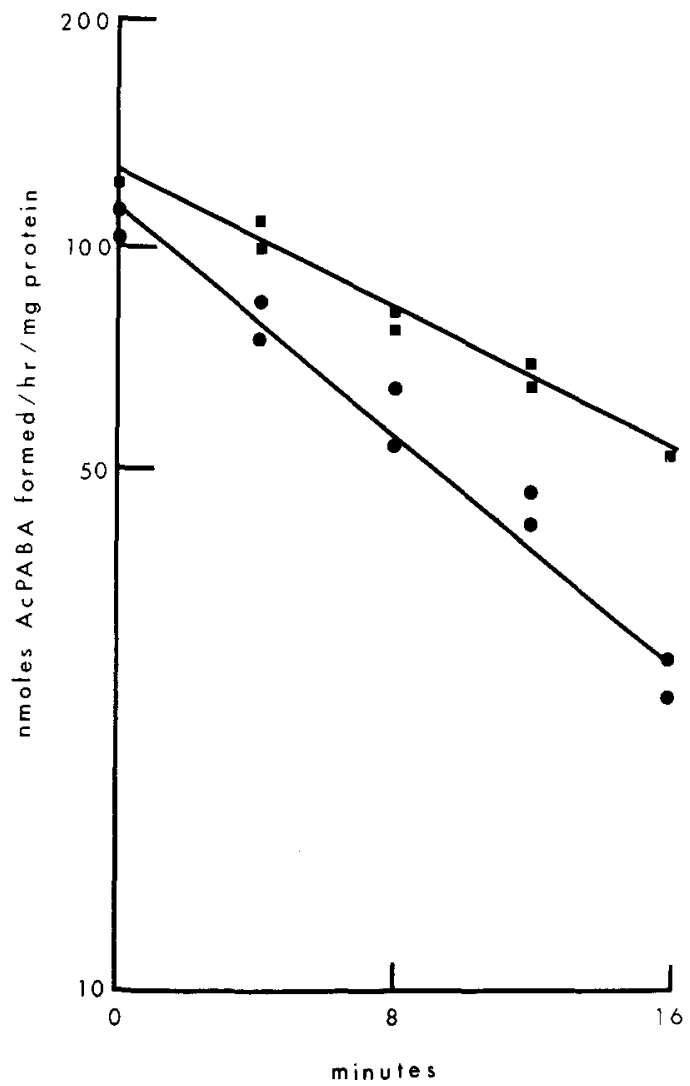

Fig. 2. Inactivation of lymphocyte NAT at $44 \mathrm{C}$. The cell lysate was heated at $44 \mathrm{C}$ for $0,4,8,12$, and $16 \mathrm{~min}$, then placed on ice. Enzyme activity was determined according to the procedure in Materials and Methods. The log of the product was plotted against the time at $44 \mathrm{C}$. The $t_{1 / 2}$ and $k$ were determined by regression analysis. Rapid INH acetylator $(\bullet) t_{1 / 2}=15 \mathrm{~min}, k=0.048$ $\min ^{-1}, r=0.99$; slow INH acetylator $(\mathbb{\square}) t_{1 / 2}=8.3 \mathrm{~min}, k=0.083 \mathrm{~min}^{-1}, r=0.97$. 
Table II. Inactivation at $44 \mathrm{C}$ of Lymphocyte NAT from Rapid and Slow INH Acetylators

\begin{tabular}{|c|c|c|c|c|c|}
\hline \multicolumn{3}{|c|}{ Slow INH acetylators } & \multicolumn{3}{|c|}{ Rapid INH acetylators } \\
\hline Donor & $k\left(\min ^{-1}\right)$ & $t_{1 / 2}(\min )$ & Donor & $k\left(\min ^{-1}\right)$ & $t_{1 / 2}(\min )$ \\
\hline GG & 0.034 & 21 & $\mathrm{vz}$ & 0.048 & 15 \\
\hline BB & 0.037 & 19 & SL & 0.057 & 12 \\
\hline $\mathrm{CH}$ & 0.043 & 16 & AA & 0.058 & 12 \\
\hline WW & 0.044 & 16 & LB & 0.061 & 11 \\
\hline RT & 0.046 & 15 & DK & 0.066 & 11 \\
\hline CS & 0.048 & 15 & SB & 0.072 & 10 \\
\hline RV & 0.048 & 15 & DR & 0.073 & 10 \\
\hline OL & 0.049 & 15 & PN & 0.078 & 8.8 \\
\hline BW & 0.050 & 14 & IG & 0.081 & 8.7 \\
\hline HR & 0.051 & 14 & PS & 0.081 & 8.6 \\
\hline $\mathrm{DG}$ & 0.053 & 13 & SH & 0.089 & 8.1 \\
\hline FC & 0.056 & 12 & $\mathrm{HE}$ & 0.091 & 8.0 \\
\hline PDS & 0.056 & 12 & ML & 0.106 & 6.6 \\
\hline DW & 0.057 & 12 & WB & 0.110 & 6.6 \\
\hline LH & 0.058 & 12 & $\mathrm{JB}$ & 0.183 & 3.8 \\
\hline KM & 0.058 & 12 & & & \\
\hline WV & 0.061 & 12 & & & \\
\hline EP & 0.061 & 12 & & & \\
\hline $\mathrm{DH}$ & 0.065 & 11 & & & \\
\hline $\mathrm{KL}$ & 0.066 & 10 & & & \\
\hline JS & 0.070 & 10 & & & \\
\hline $\mathrm{CM}$ & 0.071 & 10 & & & \\
\hline MAL & 0.076 & 9.2 & & & \\
\hline CAS & 0.107 & 6.6 & & & \\
\hline Mean & 0.056 & 13 & & 0.084 & 9 \\
\hline SD & 0.015 & 3.2 & & 0.033 & 2.7 \\
\hline$N$ & 24 & 24 & & 15 & 15 \\
\hline
\end{tabular}

heating, while at $46 \mathrm{C}$, only $20 \%$ of the enzyme activity remained. Subsequently, the stability of the enzyme was determined at 44C. Lymphocytes from 39 healthy adult volunteers, 17 females and 22 males, were used. Semilog plots of NAT activity vs. time of heating yielded straight lines (Fig. $2)$. The rate of inactivation $\left(k \mathrm{~min}^{-1}\right)$ and the half-life $\left(t_{1 / 2} \mathrm{~min}\right)$ were calculated using a semilog regression program. Lymphocyte PABA NAT from rapid acetylators was more sensitive to heating than enzyme from slow acetylators. The mean $t_{1 / 2}$ value from rapid acetylators was $9 \min (k=0.084$ $\left.\min ^{-1}\right)$ and for slow acetylators was $13 \min \left(k=0.056 \mathrm{~min}^{-1}\right)$ (Table II and Fig. 3). This difference was statistically significant $(p<0.001)$ in a Student's $t$ test.

The reproducibility of the $t_{1 / 2}$ was tested in the same cell sample and in different cell samples from the same individual. A ratio of the lowest $t_{1 / 2}$ to the highest $t_{1 / 2}$ was calculated for each individual. The average ratio for 
rapid INH acetylators

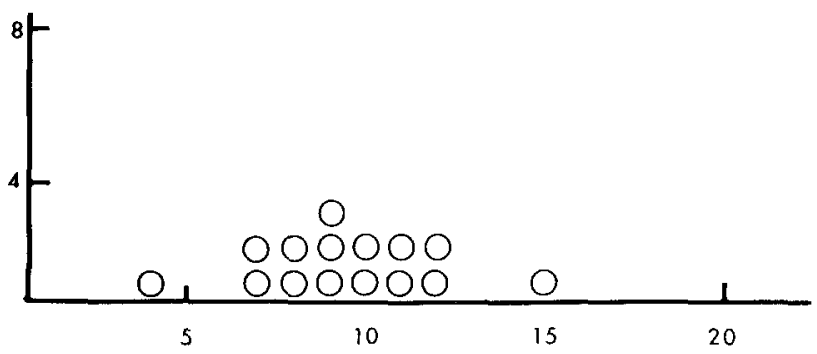

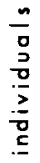

slow INH acerylators

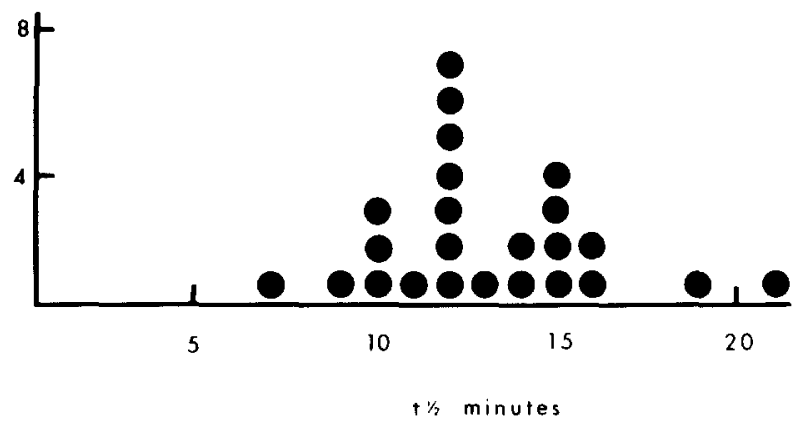

Fig. 3. Distribution of the half-life $\left(t_{1 / 2}\right)$ at $44 \mathrm{C}$ of lymphocyte NAT in rapid and slow INH acetylators.

multiple determinations using the same cell sample was 0.83 and for different cell samples obtained from the same individual it was 0.76 . This indicates that the variation seen in repeated $t_{1 / 2}$ determinations on an individual were not due to changes in the cell population of the blood sample.

The $t_{1 / 2}$ in either phenotype was not effected by dialysis of the cell lysate against $0.1 \mathrm{M}$ potassium phosphate, $p \mathrm{H} 7.0$, plus $10^{-3} \mathrm{M}$ DTT plus $10^{-3} \mathrm{M}$ EDTA before the $t_{1 / 2}$ determination. Lysing the cells in buffer with or without $10^{-3} \mathrm{M}$ DTT and/or $10^{-3} \mathrm{M}$ EDTA did not alter the heat inactivation curves.

The lymphocyte lysate from a rapid acetylator was mixed with lysate from a slow acetylator, and the $t_{1 / 2}$ and $k$ at $44 \mathrm{C}$ were determined. The $k$ value of $0.059 \mathrm{~min}^{-1}$ obtained was approximately the average of the values for the two phenotypes, $0.045 \mathrm{~min}^{-1}$ for the slow acetylator and $0.069 \mathrm{~min}^{-1}$ for the rapid acetylator. The $t_{1 / 2}$ of the mixture was $12 \mathrm{~min}$, with values of 15 $\mathrm{min}$ for the slow acetylator and $11 \mathrm{~min}$ for the rapid acetylator. 
Table III. Effect of Compounds on the Stability of Lymphocyte NAT at 44 C

\begin{tabular}{|c|c|c|c|c|c|c|c|}
\hline \multirow[b]{2}{*}{ Compound } & \multirow[b]{2}{*}{$\begin{array}{c}\mathrm{M} \\
\text { concentration }\end{array}$} & \multicolumn{3}{|c|}{$\begin{array}{c}\text { Rapid INH } \\
\text { acetylator } \\
t_{1 / 2}(\text { min })\end{array}$} & \multicolumn{3}{|c|}{$\begin{array}{c}\text { Slow INH } \\
\text { acetylator } \\
t_{1 / 2}(\min )\end{array}$} \\
\hline & & $A$ & $B$ & $\frac{B}{A}$ & $A$ & $B$ & $\frac{B}{A}$ \\
\hline $\mathrm{AcCoA}$ & $2.86 \times 10^{-3}$ & 14 & - & - & 12 & 153 & 13 \\
\hline $\mathrm{AcCoA}$ & $2.86 \times 10^{-4}$ & 14 & 206 & 15 & 12 & 123 & 10 \\
\hline $\mathrm{AcCoA}$ & $2.86 \times 10^{-5}$ & 14 & 134 & 10 & 12 & 127 & 11 \\
\hline $\mathrm{AcCoA}$ & $2.86 \times 10^{-6}$ & 14 & 221 & 16 & 12 & 91 & 8 \\
\hline $\mathrm{AcCoA}$ & $2.86 \times 10^{-7}$ & 14 & 38 & 3 & 12 & 18 & 2 \\
\hline AcINH & $1.30 \times 10^{-3}$ & 7 & 7 & 1 & 11 & 13 & 1 \\
\hline Acthiocholine & $2.86 \times 10^{-4}$ & 11 & 12 & 1 & 15 & 20 & 1 \\
\hline Actryptamine & $2.86 \times 10^{-4}$ & 8 & 9 & 1 & 11 & 15 & 1 \\
\hline INH & $1.30 \times 10^{-3}$ & 7 & 15 & 2 & 11 & 29 & 3 \\
\hline Melatonin & $2.86 \times 10^{-4}$ & 8 & 10 & 1 & 12 & 10 & 1 \\
\hline Nicotinamide & $2.86 \times 10^{-4}$ & 11 & 8 & 1 & 15 & 12 & 1 \\
\hline PABA & $5.70 \times 10^{-4}$ & 7 & 31 & 5 & 11 & 23 & 2 \\
\hline Serotonin & $2.86 \times 10^{-4}$ & 8 & 13 & 2 & 15 & 21 & 1 \\
\hline Tryptamine & $2.86 \times 10^{-4}$ & 8 & 8 & 1 & 11 & 11 & 1 \\
\hline
\end{tabular}

A variety of compounds were screened for their ability to stabilize lymphocyte NAT against heat denaturation. The test compound was added to the cell lysate and heated at $44 \mathrm{C}$, and the residual enzyme activity was determined. A ratio of the $t_{1 / 2}$ with the compound to the $t_{1 / 2}$ of the enzyme alone was calculated. A value of 1 was expected if no stabilization occurred, with the greatest stabilization giving the highest value. AcCoA was the most effective compound (Table III). A concentration of approximately $3 \times 10^{-5}$ $M$ resulted in a tenfold increase in the $t_{1 / 2}$; even a concentration of $3 \times 10^{-7} \mathrm{M}$ had an appreciable effect. PABA and INH were less effective while acetylthiocholine, serotonin, nicotinamide, acetylisoniazid (AcINH), melatonin, tryptamine, and acetyltrptamine had no effect.

\section{Cell Culture}

Cultures of freshly isolated peripheral lymphocytes, stimulated with PHA, had PABA NAT activity which peaked at $96-120 \mathrm{hr}$. The amount of activity was comparable to that in uncultured cells.

The stability at $44 \mathrm{C}$ of cells cultured for $96 \mathrm{hr}$ was tested and found to be the same as for uncultured cells. For a rapid acetylator, a $t_{1 / 2}$ of $9 \mathrm{~min}$ $k=0.080 \mathrm{~min}^{-1}$ ) was obtained after cell culture while the uncultured cells had a $t_{1 / 2}$ of $8 \mathrm{~min}\left(k=0.082 \mathrm{~min}^{-1}\right)$. The values seen for slow acetylators were $9 \min \left(k=0.080 \mathrm{~min}^{-1}\right)$ for the cultured cells as compared to $11 \mathrm{~min}$ $\left(k=0.065 \mathrm{~min}^{-1}\right)$ for the uncultured cells. 


\section{DISCUSSION}

Rabbits exhibit a polymorphism in hepatic (Frymoyer and Jacox, 1963; Gordon et al., 1973) as well as extrahepatic NATs (Weber et al., 1975, 1976; Szabadi et al., 1978). The hepatic enzyme determines the rate of acetylation of drugs such as INH, and animals are designated as rapid or slow acetylators (Frymoyer and Jacox, 1963; Gordon et al., 1973). Blood NAT metabolizes PABA, and animals are designated as having high or low levels of activity (Weber et al., 1975, 1976). A relationship exists between these two polymorphisms, with rapid INH acetylators having low blood PABA NAT activity and slow INH acetylators having high blood PABA NAT. Fractionation of rabbit blood cell samples shows that the difference in PABA NAT activity is present in the red cell and lymphocyte (Szabadi et al., 1978).

Since rabbit and man both express the liver NAT polymorphism, it was reasonable to see if the extrahepatic polymorphism is present in man as well. Because polymorphic differences can be expressed in an alteration of activity, thermal stability, $p \mathrm{H}$ optimum, or any of the biochemical properties of an enzyme (Paigen, 1971), a variety of parameters of lymphocyte NAT were tested. The purposes of this study were to characterize human lymphocyte NAT of rapid and slow INH acetylators and to seek correlations between genetically determined INH acetylator phenotypes and one or more biochemical properties of lymphocyte NAT. A comparison of the properties of human lymphocyte NAT from the two acetylator phenotypes revealed no differences in the specific activity, substrate specificity, kinetic properties, inhibition, $p \mathrm{H}$ optimum, stability to trypsin, or stability to freezing. Heat stability studies did show that lymphocyte PABA NAT from human rapid acetylators was more sensitive to inactivation at $44 \mathrm{C}$ than enzyme from slow acetylators (Table II).

The differential heat stabilities observed may be accounted for in several ways:

1. By the presence of an inhibitor of PABA NAT.

2. By the presence of a stabilizing agent of PABA NAT.

3. By the posttranslational modification of the enzyme.

4. By a structural gene difference.

Results of mixing experiments and the similarities in specific activities of the enzyme from the two acetylator phenotypes argue against the first two possibilities. When lymphocyte NAT from a rapid INH acetylator was mixed with that from a slow acetylator, the $k$ at $44 \mathrm{C}$ of the mixture was the average of the two phenotypes. If an inhibitor were present, the expected $t_{1 / 2}$ or $k$ would be like that of the less stable type, while if a stabilizing agent were 
present, the value would be more like that of the more stable phenotype. The presence of a stabilizer or an inhibitor should also be reflected in the specific activity of lymphocyte NAT. The phenotype with the inhibitor would be expected to have a low specific activity while the phenotype with the stabilizer would have a high specific activity. No such differences were seen in the specific activity of human lymphocyte NAT in the rapid or slow INH phenotypes (Table I), although rabbit blood NAT did show differences in specific activity which, it has been postulated, may be due to a stabilizing agent inactivated by the polymorphic NAT. Greater amounts of this substance would be present in slow acetylators since they have a lower liver NAT activity than rapid acetylators (Szabadi et al., 1978). The only substance that had a substantial effect on the heat stability of human lymphocyte NAT was the acetyl donor substrate of the reaction, AcCoA (Table III). A stable acetyl enzyme intermediate could be formed by the lymphocyte enzyme which seems to have the same kinetic mechanisms as the rabbit liver enzyme. Initial velocity studies of both rabbit liver NAT (Weber and Cohen, 1963; Weber et al., 1968) and human lymphocyte NAT showed a series of parallel lines. Differences in the concentration of AcCoA in rapid and slow acetylators, then, could effect the stability of the lymphocyte enzyme. Dialysis of the enzyme, however, did not change the stability of lymphocyte NAT, ruling out the presence of a dialyzable stabilizer, like AcCoA, or an inhibitor.

The biochemical characteristics of an enzyme such as heat stability can be altered by posttranslational modifications of the enzyme. Studies of murine kidney catalase isolated from inbred strains $\mathrm{C} 3 \mathrm{H}$ and $\mathrm{C} 57 \mathrm{~B} 1 / 6$ indicated that they were electrophoretically different (Hoffman and Grieshaber, 1976). Breeding studies done with these strains showed the electrophoretic pattern from the $F_{1}$ generation to be identical to that of C57B1/6 parent. If enzyme from the parental strains was mixed and then subjected to electrophoresis, the pattern of the C57B1/6 parent was seen. This suggests that some posttranslational modification had converted $\mathrm{C} 3 \mathrm{H}$ type to the C57B $1 / 6$ type.

A similar pattern of events was seen with human adenosine deaminase, where different tissues give different electrophoretic patterns. Mixing of homogenates from one tissue (e.g, RBCs) with another (e.g., kidney) was followed by electrophoresis which resulted in a single pattern (kidney) (Hirshhorn, 1975).

Although it is possible that the differential heat stability seen in lymphocyte NAT could be due to a posttranslational modification, the results of mixing experiments previously described were not consistent with this. Electrophoresis, the technique used in the studies described above, was not 
done with lymphocyte NAT because a staining technique for this enzyme is not available.

The final explanation for the differential heat stability seen in human lymphocyte NAT is a structural gene difference. While evidence from this study is consistent with that hypothesis, further work is necessary to demonstrate the nature of the differences. The ultimate way to determine an alteration in a structural gene is amino acid sequencing, which requires a highly purified preparation of the enzyme. Even techniques such as peptide mapping that could detect amino acid differences require a more highly purified enzyme than is presently available.

Studies with bovine carboxypeptidase $A$ in which the amino acid sequences were determined do support the possibility of a structural gene difference accounting for differential heat stability. Two forms of the enzyme having the same specific activities were isolated from pancreatic tissue. One form of the enzyme had a $t_{1 / 2}$ at $50 \mathrm{C}$ of about $25 \mathrm{~min}$ and the other a value of about $50 \mathrm{~min}$. Sequencing of the terminal peptide showed they differed only in the $C$-terminal amino acid. The more stable form of the enzyme contained valine, and the less stable form contained leucine (Walsh et al., 1966).

A limited study was done to determine if the differential heat stability had a genetic component. Data obtained on three human families were consistent with the $t_{1 / 2}$ and $k$ of lymphocyte NAT being determined by a two-allele system, but more extensive family studies would be necessary to confirm this hypothesis.

Among the several species of mammals which have been studied, a relationship is always observed between liver INH phenotype and extrahepatic NAT, but the nature of this relationship varies from one species to another. Deer mice show a direct correlation between liver NAT activity and blood PABA NAT (Tanner and Weber, 1977). Rabbits, on the other hand, show an inverse relationship, which rapid INH acetylators having low levels of blood PABA NAT and slow INH acetylators having high blood PABA NAT activity (Weber et al., 1976; Szabadi et al., 1978). Biochemical studies of rabbit liver NAT and blood NAT indicate common structural features for the enzyme from these tissues (Weber et al., 1975). Recent studies of the heat stability and immunological characteristics of hepatic NAT from rapid and slow INH acetylator rabbits provide strong evidence for a structural difference accounting for the INH acetylator polymorphism (Weber et al., 1978). In this report, we described a relationship between the human liver INH acetylator phenotype and the heat stability of lymphocyte NAT: rapid acetylators have a lymphocyte NAT that is less heat stable than the lymphocyte enzyme from a slow acetylator (Table II). In view of the correlation between human lymphocyte NAT and acetylator phenotype and 
the evidence from rabbit studies, it may be anticipated that there is also a structural difference in human hepatic NAT which accounts for the INH acetylator polymorphism. Further studies are necessary to clarify the relationship between lymphocyte NAT and the hepatic enzyme.

\section{REFERENCES}

Bloom, A. D., and lida, S. (1967). Two day leukocyte cultures for human chromosome studies. Jpn. J. Hum. Genet. 12:38.

Böyum, A. (1967). Isolation of mononuclear cells and granulocytes from human blood. J. Clin. Lab. Invest. 21:77 (Suppl. 97).

Drayer, D. E., Strong, J. M., Jones, B., Sandler, A., and Reidenberg, M. M. (1974). In vitro acetylation of drugs by human blood cells. Drug Metab. Disp. 2:499.

Evans, D. A. P. (1969). An improved and simplified method of detecting the acetylator phenotype. J. Med. Genet. 6:405.

Evans, D. A. P., Manley, K. A., and McKusick, V. A. (1960). Genetic control of isoniazid metabolism in man. Br. Med. J. 2:485.

Frymoyer, J. W., and Jacox, R. F. (1963). Investigation of the genetic control of sulfadiazine and isoniazid metabolism in the rabbit. J. Lab. Clin. Med. 62:891.

Gordon, G. R., Shafizadeh, A. G., and Peters, J. H. (1973). Polymorphic acetylation of drugs in rabbits. Xenobiotica 3:133.

Gornall, A. G., Bardawill, C. S., and David, M. M. (1949). Determination of serum proteins by means of the biuret reaction. J. Biol. Chem. 177:751.

Hearse, D. J., Weber, W. W., and Pretorious, H. T. (1970). Multiple $N$-acetyltranserases and their relationship to drug toxicity. Am. J. Hum. Genet. 22:15A.

Hearse, D. J., and Weber, W. W. (1973). Multiple $N$-acetyltransferases and drug metabolism. Biochem. J. 132:519.

Hirshhorn, R. (1975). Isozymes of adenosine deaminase. In (ed.). C. L. Market, Isozymes, Vol. 2, Academic Press, New York, pp 583-599.

Hoffman, H. A., and Grieshaber, C. K. (1976). Genetic studies of murine catalase: Regulation of multiple molecular forms of kidney catalase. Biochem. Genet. 14:59.

Knight, R. A., Selin, M. J., and Harris, H. W. (1959). Genetic factors influencing isoniazid blood levels in humans. Tr. Conf. Chemother. Tuberc. 18:52.

Lipmann, F. (1945). Acetylation of sulfamethazine by liver homogenates and extracts. $J$. Biol. Chem. 160:173.

Lopes, J., Nachbar, M., Zucker-Franklin, D., and Silber, R. (1973). Lymphocyte plasma membranes: Analysis of proteins and glycoproteins by SDS gel electrophoresis. Blood 41:131.

Motulsky, A. G., and Steinmann, L. (1962). Aryl amine acetylation in human red cells. J. Clin. Invest. 41:1387.

Paigen, K. (1971). The genetics of enzyme realization. In Recheigal, M., Jr. (ed.), Enzyme Synthesis and Degradation in Mammalian Systems, Karger, Basel, pp 1-46.

Szabadi, R. R., McQueen, C. A., Drummond, G. S., and Weber, W. W. (1978). N-Acetylation of drugs: A genetically controlled reciprocal relationship between drug $N$-acetylating enzymes of rabbit liver and peripheral blood cells. Drug Metab. Disp. 6:16.

Tannen, R., and Weber, W. W. (1977). Phenotypic variation of $\mathrm{N}$-acetylation of drugs in two genetically related populations of decrmice. Fed. Proc. 36:1018.

Walsh, K. A., Ericsson, L. H., and Neurath, H. (1966). Bovine carboxypeptidase A variants resulting from allelomorphism. Proc. Natl. Acad. Sci. 56:1339.

Weber, W. W., and Cohen, S. N. (1968). The mechanism of isoniazid acetylation by human $N$-acetyltransferase. Biochim. Biophys. Acta 151:276. 
Weber, W. W., and Brenner, W. (1974). A filter paper method for determining isoniazid acetylator phenotype. Am. J. Hum. Genet. 26:467.

Weber, W. W., Cohen, S. N., and Steinberg, M. S. (1968). Purification and properties of $N$-acetyltransferases from mammalian liver. Ann. N.Y. Acad. Sci. 151:734.

Weber, W. W., Drummond, G. S., Miceli, J. N., and Szabadi, R. (1975). Genetic control and isozymic compositon of drug acetylation enzymes. In Market, C. L. (ed.), Isozymes, Vol. 5 , Academic Press, New York, pp. 813-828.

Weber, W. W., Miceli, J. N., Hearse, D. J., and Drummond, G. S. (1976). N-Acetylation of drugs: Pharmacogenetic studies in rabbits selected for their acetylator characteristics. Drug Metab. Disp. 4:94.

Weber, W. W., Hein, D. W., Hirata, M., and Patterson, E. (1978). Genetics of drug acetylation: Molecular nature of the INH acetylation polymorphism. In Aitio, A. (ed.), Conjugation Reactions in Drug Biotransformation, Elsevier/North Holland Biomedical Press, New York, pp 145-153. 